\title{
Erratum to: Goby and shrimp associations: more than meets the eye
}

\author{
Z. Jaafar • W. Tan $\cdot$ D. Chen
}

Published online: 27 April 2014

(c) Springer-Verlag Berlin Heidelberg 2014

Erratum to: Coral Reefs (2014)

DOI 10.1007/s00338-014-1143-4

This erratum is to denote the following discrepancies noted in the original publication:

Addition of W. Tan as the second author (no academic affiliation).

C. Dexiang to change to D. Chen, currently the second author, but now to be the third.

The online version of the original article can be found under doi:10.1007/s00338-014-1143-4.

Z. Jaafar $(\square)$

Department of Biological Sciences, National University of

Singapore, Singapore 117543, Singapore

e-mail: jaafarz@si.edu

Present Address:

Z. Jaafar

Division of Fishes, National Museum of Natural History,

Smithsonian Institution, Washington, DC 20004, USA

W. Tan · D. Chen

National Parks Board, 1 Cluny Road, Singapore 259569,

Singapore 